for the equinox $1900 \cdot 0$, and the proper motions are given for both amount and direction. Remarks regarding uncertainties in proper motions are added, and in the case of double stars, the number in Burnham's General Catalogue is given. Attention is directed to a list by Innes of proper-motion stars south of $-19^{\circ}$; this appeared subsequent to the printing of the present paper, and Mr. van Maanen adds the numbers of Innes's list which should be included in his communication.

Orbits of Variable Radial Velocity Stars.-In the April number of the Journal of the Royal Astronomical Society of Canada some reductions are given of the measures of the variable radial velocities of stars. The orbit of I36 Tauri, deduced by J. B. Cannon, is based on sixty plates taken at the Ottawa Dominion Observatory between November, IgII, and January, I9I5. The paper gives a list of the observations. The spectrum of this star is of the A type, and the deduced period is 5.969 days. The same writer deals also with the orbit of $\xi$ Andromedæ, a star of the $\mathrm{K}$ type spectrum, and utilises. fifty-eight plates taken at the same observatory, between September, r9I3, and February, I9I5. On the average about twelve lines were measured on each plate, and, generally speaking, the agreement was very fair. The final period derived was 17.767 days. In both of the above stars comparisons are made with the Lick Observatory results. The orbits of the spectroscopic components of 50 Draconis are discussed by W. E. Harper from the velocities of the ten plates secured at the Yerkes Observatory, and thirty-four taken at the Dominion Observatory. Both spectra were of the A type. The Yerkes and Ottawa observations both indicate a period of 4.120 days. The determination of the orbit of the spectroscopic hinary, II49 Groombridge, was also undertaken by the same writer using thirty spectrograms secured at Ottawa and three secured by Adams. The star is of the A5 type, and the spectrum has numerous lines well adapted for measurement. In the list of final elements derived the period is given as 9.944 days.

Manchester Astronomical Society.-No. $I$ of the Journal of the Manchester Astronomical Society, for the session I9I3-I4, gives a brief account of the origin of the society and a statement as to its growth since its foundation in : 1903. The object is for the association of amateur astronomers, for mutual help, their organisation in the work of astronomical observation, and the encouragement of a popular interest in astronomy. The society numbers at present I3I members, and its president is the Rev. A. L. Cortie, S.J. The journal gives excellent portraits of the present and past four presidents; and the address of the president on the origin of the sun and stars is printed and illustrated with three plates. A paper on Japanese and other magic mirrors is from the pen of the late Mr. T. Thorp, who was an original and active member of the society. Lunar photography, by Mr. William Porthouse; astronomy and æsthetics, by Mr. E. Denton Sherlock; and a remarkable solar prominence, by $\mathrm{Mr}$. A. Buss, form the subjects of other papers printed in this issue.

\section{CONSTITUENTS OF EXTRACTS DERIVED FROM ALBUMINOUS SUBSTANCES.}

A JOINT meeting of the Society of Public Analysts and the Biochemical Society, which was held at the Chemical Society's Rooms on May 5, was devoted to the discussion of the methods adopted in estimating the nitrogenous constituents of extracts derived from albuminous substances, such as meat extracts. $\mathrm{Mr}$.
A. Chaston Chapman, the chairman, in opening the discussion, pointed out that from the technical point of view the purposes to be served by such analyses were, first, to indicate the general character of the process by which any particular extract had been prepared; secondly, to throw some light on the source of the extract and its genuineness or otherwise; and, finally, to furnish information as to the physiological properties of dietetic value. He then gave an outline of the existing methods of analysis, and emphasised their limitations; more particularly the practice of returning the "residual nitrogen" as "meat bases," using the factor 3.12 for the conversion was a source of uncertainty and confusion, especially as Hehner had suggested the use of the ordinary protein factor, 6.25, for the same purpose. The best plan was to return the actual nitrogen percentages.

Dr. F. Gowland Hopkins; dealing with the question of the food value of meat extracts and similar preparations, pointed out that the animal body dealt not with the intact proteins, or even with the albumoses and peptones, but with the free amino-acids which were the individual constituents of the protein molecules. The way in which these acids were grouped in the protein molecule was not of much consequence, but the effects produced by the individual amino-acids were of extreme importance. He described physiological experiments which he had made showing that when rats were given a diet including a complete amino-acid mixture corresponding with the proteins of an ordinary diet, the growth was almost exactly normal, but when arginine and histidine were removed from the mixture, growth ceased immediately, but was again resumed when the missing constituents were added. The removal of tryptophane produced similar results, and Osborne and Mendel had, in America, shown that cystine was similarly essential. It did not follow that this was the case with every amino-acid, and the question as to which of these were vitally nezessary offered a large field for investigation. Experiment had shown that in the case of rats, the critical minimum for arginine lay somewhere between $2 \frac{1}{2}$ and $I$ per cent. The functions of the individual amino-acids were not confined merely to flesh formation. Thus, for example, the effect of feeding animals on zein, which was deficient in both tryptophane and lysine, was not only to restrict growth, but to shorten the survival; the same was true with zein plus lysine, but with zein plus tryptophane the animal was able to maintain its weight for a long period, although it did not grow.

Dr. E. P. Cathcart said that observations at present available were so scanty that it could not be said with certainty that creatine and creatinine had a special niche in the organism. He did not think that any end would be gained by the separate estimation of these two substances. Mr. A. R. Tankard and Mr. E. Hinks dealt with questions of procedure, and Dr. Percival Hartley described his experience of Van Slyke's method of estimating amino-nitrogen; further remarks were made by Dr. Rideal, Prof. Barger, Dr. Harden, and Dr. S. Walpole.

\section{MUSEUMS AND EDUCATION.}

THE Museums Journal for May contains an interesting and suggestive article on the educational work of American museums, by the director of the Charleston Museum. It is abundantly clear from this that the functions of the museum in America are, so to speak, intensively cultivated. And nowhere is this more apparent than in the facts which he gives in regard to the co-operation which has grown up between the museums and the public schools. It is now the rule, he tells us, for children to be brought NO. 2379, VOL. 95] 